\title{
Interfacial Behavior of Fatty-Acylated Sericin Prepared by Lipase-Catalyzed Solid-Phase Synthesis
}

\author{
Masato Ogino, ${ }^{1}$ Rie Tanaka,,${ }^{1}$ Makoto Hattori, ${ }^{1}$ Tadashi Yoshida, \\ Yoshiko YoKote, ${ }^{2}$ and Koji TAKAHASHI ${ }^{1, \dagger}$ \\ ${ }^{1}$ Department of Applied Biological Science, Faculty of Agriculture, \\ Tokyo University of Agriculture and Technology, Tokyo 183-8509, Japan \\ ${ }^{2}$ Department of Chemistry, Faculty of Science, Josai University, Saitama 350-0248, Japan
}

Received May 18, 2005; Accepted September 5, 2005

Fatty-acylated sericin $\{1: 0.7$ molar ratio of sericin $\left(M_{\mathrm{r}}\right.$ 18,700) to oleic acid\} was prepared by lipasecatalyzed solid-phase synthesis in $\boldsymbol{n}$-hexane containing oleic acid to endow sericin with interfacial properties. Acylation with oleic acid was confirmed by ${ }^{1} \mathrm{H}$-NMR. The fatty-acylated sericin exhibited superior emulsifying activity index and emulsion stability in the presence of $0-0.5 \mathrm{M} \mathrm{NaCl}$, in a temperature range of $30-80^{\circ} \mathrm{C}$ and pH range of 2-7, as compared with the control sericin. The fatty-acylated sericin (1:0.4 molar ratio) prepared by using low-molecular-weight sericin $\left(M_{\mathrm{r}} \mathbf{5 , 0 0 0 )}\right.$ also exhibited superior emulsifying properties. The affinity of the fatty-acylated sericin to a hydrophobic surface as evaluated by a biomolecular interaction analyzer was about twice as much as that of the control sericin. The fatty-acylated sericin showed retarded water vaporization, similar to the control sericin, indicating good retention of moistness, and was adsorbed four times as much to defatted wool with little desorption as compared with the control sericin.

Key words: sericin; acylation with lipase; interfacial behavior; emulsifying ability; moistness

Sericin, a silk protein, is the main constituent of silk (20-30\% of the total cocoon weight), enveloping fibroin with successive sticky layers. ${ }^{1)}$ Most sericin is removed from the cocoon by heating in water to produce silk textiles, and disposed of without higher utilization. The amino acid composition of sericin is characterized by its very high contents of serine, aspartic acid and glycine, and low contents of basic and non-polar amino acids, ${ }^{2)}$ resulting in a highly hydrophilic and acidic protein. It has recently been found that sericin has such functional properties as water-holding capacity or moistness, ${ }^{3)}$ cryoprotectitvity, ${ }^{4)}$ improvement of constipation due to its indigestibility ${ }^{5)}$ and absorption of minerals, ${ }^{6)}$ antioxidative activity, ${ }^{2)}$ tyrosinase-inhibitory activity, ${ }^{2)}$ and suppression of tumorigenesis. ${ }^{7)}$ In addition, sericin has been applied to develop biodegradable materials, functional membrane materials, and functional biomaterials and fabrics ${ }^{8)}$ including such chemical modifications as the sulfation of sericin to endow anticoagulative activity. ${ }^{9)}$ These attempts suggest the possibility of new applications to foods, cosmetics, and other industrial uses. However, sericin has only found general application to cosmetics. If sericin could be given an amphihilic property by means of suitable modification, the modified sericin can be expected to exhibit such interfacial properties as adsorption to a hydrophobic surface, emulsification, and moisturization. However, there has been no study on the interfacial behavior of sericin. The fatty-acylation of sericin is thus thought to be effective for endowing an amphihilic property that would result in interfacial behavior.

Fatty acylation of protein can be carried out by chemical or enzymatic modification. Chemical modifications such as the palmitoylation of soybean glycinin, ${ }^{10)}$ lypophilization of $\alpha$ S1casein, ${ }^{11)}$ and acylation of lysozyme ${ }^{12,13)}$ have resulted in improved functions such as emulsifying properties and antibacterial activity. However, to use such acylated proteins for food application, an acylation method is necessary that does not require any chemical reagents, as the Maillard reaction has been applied to conjugate lysozyme with a fatty-acylated saccharide. ${ }^{14)}$ Enzymatic modification with the reverse reaction and rearrangement reaction of lipase (triacylglycerol acylhydrolase, EC 3.1.1.3) in a non-aqueous solvent or solvent-free system has been carried out to synthesize a capsinoid ester, ${ }^{15)}$ ascorbyl ester, ${ }^{16)}$ monacylglycerol, ${ }^{17)}$ flavor and fragrance esters, ${ }^{18)}$ and a sugar ester. ${ }^{19)}$ An organic solvent having a little solvent power is generally used to promote lipasecatalyzed ester synthesis. In many cases, the substrate as an acyl acceptor is thus confined to a relatively lowmolecular-weight substance. In this present study, lipase-catalyzed solid-phase synthesis in $n$-hexane was applied to fatty-acylate sericin with different molecular

\footnotetext{
$\dagger$ To whom correspondence should be addressed. Tel: +81-42-367-5712; Fax: +81-42-360-8830; E-mail: k-taka@cc.tuat.ac.jp
} 
weights that would be insoluble in organic solvents and to elucidate the chemical features and interfacial properties endowed such as adsorption to a hydrophobic surface, emulsifying ability, and moisturization resulting from its adsorption.

\section{Materials and Methods}

Materials. Sericin was obtained by extracting the dried white cocoon with electrolytic alkaline water (pH 11.5) at $95^{\circ} \mathrm{C}$ for $7 \mathrm{~h}$, before dialyzing the resulting sericin solution (sericin MY-30N, Shinko Silk, Wakayama, Japan) against water, centrifuging at 12,000 rpm for $30 \mathrm{~min}$, passing through a membrane filter $(0.45 \mu \mathrm{m}$ pore size; Advantech, Tokyo, Japan), and lyophilizing. This sericin preparation is referred to as the original sericin. A low-molecular-weight sericin preparation (LM sericin) was obtained by extracting the dried white cocoon with electrolytic alkaline water at $95^{\circ} \mathrm{C}$ for $13 \mathrm{~h}$, and lyophilizing the extract without dialysis. Novozym 435 (Candida antratica lipase immobilized on macroporous acrylic resin, 10,000 PLU/g) was obtained from Novozyme Japan (Chiba, Japan). Oleic acid (> 60\% purity), $n$-hexane, bovine serum albumin (BSA), 3A $1 / 16$ molecular sieves, and the other reagents were purchased from Wako Pure Chemical Ind. (Osaka, Japan). The molecular sieves were dried at $400{ }^{\circ} \mathrm{C}$ for $4 \mathrm{~h}$ before being used, and $n$-hexane was dehydrated by adding the molecular sieves.

Preparation of the fatty-acylated sericin. Sericin (1 g) in a screw-capped Erlenmeyer flask was dried at $110^{\circ} \mathrm{C}$ for $1 \mathrm{~h}$, before $50 \mathrm{ml}$ of dehydrated $n$-hexane was poured in. After pulverizing with a Polytron PTA-7 homogenizer (Kinematica, Switzerland) at 24,000 rpm for $1 \mathrm{~min}$, $2 \mathrm{~g}$ of molecular sieves were added, and the mixture was de-aerated under reduced pressure for $30 \mathrm{sec}$ at room temperature. Oleic acid $(3.5 \mathrm{ml})$ and $10 \mathrm{~g}$ of Novozym 435 were next added, and the headspace gas was replaced with nitrogen gas. The reaction mixture was incubated at $60^{\circ} \mathrm{C}$ for $96 \mathrm{~h}$ while shaking at $60 \mathrm{cycle} /$ min. The reaction product was passed through a stainless steel mesh to remove the molecular sieves, and then passed through a membrane filter $(0.45 \mu \mathrm{m}$ pore size; Advantech, Tokyo, Japan) to recover the residue. This residue was dispersed in chloroform $/ n$-hexane $(5: 1$, $\mathrm{v} / \mathrm{v}$ ), and the dispersion was centrifuged at 3,000 rpm for $5 \mathrm{~min}$ to separate Novozym 435 as the supernatant and the crude fatty-acylated sericin as the precipitate from the suspension. The crude fatty-acylated sericin obtained was washed with $n$-hexane by centrifuging 3 times to eliminate any unreacted oleic acid, and dissolved in distilled water, before dialyzing against distilled water and lyophilizing to recover it. The crude fatty-acylated LM sericin was obtained by lyophilizing the solution that had been dissolved in distilled water without dialysis. A similarly treated sample without adding Novozym 435 was prepared as a control.
The crude fatty-acylated sericin was dissolved in a $0.2 \mathrm{M}$ acetate buffer ( $\mathrm{pH} 4.5$ ) to give a $1 \%$ solution, and this solution was treated overnight with $35 \%$ saturated ammonium sulfate at $4^{\circ} \mathrm{C}$. After centrifuging at 12,000 rpm for $30 \mathrm{~min}$ at $4{ }^{\circ} \mathrm{C}$, the resulting precipitate was dissolved in distilled water, adjusted to $\mathrm{pH} 7.0$, and then dialyzed against distilled water. The purified fattyacylated sericin was obtained by lyophilization. In the case of the crude fatty-acylated LM sericin, a $1 \%$ solution was treated with $20 \%$ saturated ammonium sulfate before centrifugation. The resulting precipitate was dissolved in distilled water, dialyzed against distilled water with a Spectra/Por membrane (1,000 molecular cut off; Spectrum Lab., Rancho Dominguea, U.S.A.), and finally lyophilized to recover the fatty-acylated LM sericin.

Size-exclusion chromatography (SEC). SEC of the fatty-acylated sericin and original sericin was carried out with a TSKgel G3000SW $\mathrm{XL}$ column (7.8 i.d. $\times 300$ $\mathrm{mm}$; Tosoh, Tokyo, Japan) that had been equilibrated with a $0.05 \mathrm{M}$ phosphate buffer $(\mathrm{pH} 7.0$ ) containing $0.3 \mathrm{M}$ $\mathrm{NaCl}$. A sample $(50 \mu \mathrm{l} ; 1 \mathrm{mg} / \mathrm{ml})$ was applied to the column, and eluted at a flow rate of $1 \mathrm{ml} / \mathrm{min}$ with the same buffer. The absorbance was monitored at $230 \mathrm{~nm}$. SEC for LM sericin was carried out by using a Superdex Peptide 10/300 column (10 i.d. $\times 300 \mathrm{~mm}$; Amersham Bioscience, Tokyo, Japan) and $0.02 \mathrm{M}$ phosphate buffer $(\mathrm{pH} 7.0)$ containing $0.25 \mathrm{M} \mathrm{NaCl}$ at a flow rate of $0.8 \mathrm{ml} /$ min as the mobile phase.

Measurement of ${ }^{1} \mathrm{H}-\mathrm{NMR}$. The ${ }^{1} \mathrm{H}-\mathrm{NMR}$ spectra of sericin and the fatty-acylated sericin were obtained to confirm the acylation at $600 \mathrm{MHz}$ with an AL-600 ${ }^{1} \mathrm{H}-$ NMR spectrometer (Jeol, Tokyo, Japan). The sample ( $2 \mathrm{mg}$ ) was dissolved in $2 \mathrm{ml}$ of $\mathrm{D}_{2} \mathrm{O}$ (Merck, Darmstadt, Germany), and then passed through a $0.45 \mu \mathrm{m}$ membrane filter (Amersham Bioscience, Tokyo, Japan). A 14-h scan was carried out at $25^{\circ} \mathrm{C}$ for each spectrum.

Measurement of FT-IR. The FT-IR spectra of sericin and the fatty-acylated sericin were measured to obtain the secondary structure by a JIR-5500 FT-IR spectrometer (Jeol, Tokyo, Japan) equipped with a microfacility and MCT detector. The sample was mounted on a thin $\mathrm{KBr}$ plate for permeation measurement. For each spectrum, a 100-scan interferogram was collected at a $4-\mathrm{cm}^{-1}$ resolution, and apodized with a triangular function to give the spectrum in its transmission mode. The second-derivative spectrum was obtained by using GRAMS/32 ver. 5.0. Smoothing was accomplished with the 11-point Savisky-Golay function, and the secondary structural contents were estimated from the peak area of the second-derivative spectrum according to the method previously described. ${ }^{20}$ ) The peaks in the wavelength range of $1,600-1,700 \mathrm{~cm}^{-1}$ were generally assigned according to the results of Dong et al. ${ }^{21)}$ and Beer et al., ${ }^{22)}$ as follows: $1,626 \mathrm{~cm}^{-1}, 1,637 \mathrm{~cm}^{-1}$ and 1,693 
$\mathrm{cm}^{-1}, \beta$-sheet; $1,672 \mathrm{~cm}^{-1}, 1,680 \mathrm{~cm}^{-1}, 1,684 \mathrm{~cm}^{-1}$ and $1,687 \mathrm{~cm}^{-1}$, turn; $1,616 \mathrm{~cm}^{-1}$, unordered. However, the major peak at $1,653 \mathrm{~cm}^{-1}$ was assigned in this experiment to an unordered structure, because sericin had a random coil structure. ${ }^{23,24)}$

Evaluation of the emulsifying properties. Sericin and the fatty-acylated sericin were dissolved in a $0.05 \mathrm{M}$ citrate- $\mathrm{HCl}$ buffer ( $\mathrm{pH} 2.0$ ) and $0.1 \mathrm{M}$ phosphate- $0.05 \mathrm{M}$ citric acid buffer ( $\mathrm{pH} 2.0,3.0,4.0,5.0$, or 7.0) at a final concentration of $0.1 \%$. The sample solution $(2 \mathrm{ml})$ and $0.5 \mathrm{ml}$ of corn oil in a test tube $(18$ i.d. $\times 85 \mathrm{~mm})$ were homogenized by a Polytron PTA-7 homogenizer (Kinematica, Switerland) at $24,000 \mathrm{rpm}$ for $1 \mathrm{~min}$ at $25^{\circ} \mathrm{C}$. The emulsion was diluted 50-fold with a $0.1 \%$ SDS solution $0,10,30,60$, and $120 \mathrm{~min}$ after emulsification, and the absorbance at $500 \mathrm{~nm}$ was measured according to the method previously described. ${ }^{14)}$ The emulsifying activity index (EAI) was calculated by the following equations: ${ }^{25)}$

$$
\mathrm{EAI}=2 T / \phi C, \text { and } T=2.3 A / L
$$

where $A$ is the absorbance at $500 \mathrm{~nm}$; $L$ (light path) is $10^{-2} \mathrm{~m} ; C$ is the concentration of a sample $\left(10^{3} \mathrm{~g} / \mathrm{m}^{3}\right)$; and $\phi$ (oil phase volume) is 0.2 . The emulsion stability was determined by the absorbance $30 \mathrm{~min}$ after emulsification.

The particle size distribution of oil droplets 0 and 60 min after emulsification in a similar manner was measured as the ratio of each oil droplet volume to the total oil droplet volume by using the emulsion diluted with $0.1 \%$ SDS to give about 0.2 absorbance at $500 \mathrm{~nm}$ by an SALD-2100J laser diffraction particle size analyzer (Shimadzu, Kyoto, Japan) according to the method previously described. ${ }^{14)}$

Evaluation of the sample amount adsorbed to oil droplets. The $\mathrm{O} / \mathrm{W}$ emulsions were prepared with sericin and the fatty-acylated sericin by the method already described, and $1.5 \mathrm{ml}$ of the emulsion from the lowest layer was taken $0 \mathrm{~min}$ or $60 \mathrm{~min}$ after emulsification. After centrifuging at $1,000 \mathrm{rpm}$ for $5 \mathrm{~min}$ to separate into the oil phase and water phase, $1 \mathrm{ml}$ of the separated water phase was taken, and centrifuged at $20,000 \mathrm{rpm}$ for $30 \mathrm{~min}$. After $0.7 \mathrm{ml}$ of the resulting water phase had been diluted 2-fold with a $0.1 \mathrm{M}$ phosphate- $0.5 \mathrm{M}$ citric acid buffer $(\mathrm{pH} 7.0)$, the solution was centrifuged at 20,000 rpm for $30 \mathrm{~min}$. This operation was conducted twice to obtain a completely clear water phase, and then the protein concentration of the final water phase was measured by the microbiuret method. ${ }^{26)}$ The amount of a sample adsorbed to the oil droplets was estimated from difference between the concentration of the initial water phase and that of the final water phase.

Evaluation of the hydrophobic interaction by IAsys. The interaction between the fatty-acylated sericin and the hydrophobic surface of a hydrophobic cuvette, with a hexadecyl group as the ligand of the resonant layer corresponding to palmitic acid, was examined by an IAsys plus biomolecular interaction analyzer (Affinity Sensors Co., Cambridge, UK). A sample solution at a concentration from $7.83 \times 10^{-4}$ to $1.25 \times 10^{-2} \%$ (from 0.048 to $0.764 \mu \mathrm{M})$ in a $0.1 \mathrm{M}$ phosphate $-0.05 \mathrm{M}$ citric acid buffer ( $\mathrm{pH} 7.0$ ) was applied to the hydrophobic cuvette containing $40 \mu \mathrm{l}$ of the same buffer, and the association with the hydrophobic surface was monitored by the resonant angle of the laser light at $670 \mathrm{~nm}$. After the detected association curve had been equilibrated, the sample was dissociated with $50 \mu \mathrm{l}$ of the same buffer, and the cuvette was washed with 2-propanol. The pseudo first-order rate constant $\left(K_{\mathrm{on}}\right)$ was obtained from the single exponential equation describing the association data for each sample concentration by FASTfit analytical software. Using a near least-quares regression, the association rate constant $\left(K_{\text {ass }}\right)$ and dissociation rate constant $\left(K_{\text {diss }}\right)$ were respectively derived from the gradient and intercept of the plot of $K_{\text {on }}$ against the sample concentration. The dissociation constant $\left(K_{\mathrm{D}}=K_{\text {diss }} / K_{\text {ass }}\right)$ was then obtained.

Evaluation of the moistness properties. The moistness properties of sericin and of the fatty-acylated sericin were evaluated by measuring the vaporization characteristics with a TG/DTA 6200 coupled thermogravimeter (TG) and differential thermal analyzer (DTA) (SII Nanotechnologies, Chiba, Japan). A sample solution $(2.0 \% \mathrm{w} / \mathrm{v}, 30 \mathrm{mg})$ was weighed in a platinum pan, and the change of weight was immediately measured at a heating rate of $5 \mathrm{~K} / \mathrm{min}$ by using a sapphire plate as a reference. The derived TG (DTG) curve was obtained, and the temperature at the maximum rate of vaporization $\left(T_{V_{\max }}\right)$, the maximum rate of vaporization itself $\left(V_{\max }\right)$, the temperature at the end of vaporization $\left(T_{\text {end } V}\right)$, and the final rate of vaporization $\left(V_{\text {end }}\right)$ were respectively derived from the temperature at the peak of the DTG curve, the vaporization rate at the peak of the DTG curve, the extrapolated temperature around $120^{\circ} \mathrm{C}$, and the vaporization rate at the extrapolated temperature around $120^{\circ} \mathrm{C}$.

Evaluation of the adsorption to defatted wool. Commercial white merino wool (Italy) was defatted with a $1 \%$ Extran solution (Merck, Darmstadt, Germany) adjusted to $\mathrm{pH} 7.0$ at $80^{\circ} \mathrm{C}$, and then successively washed thoroughly with distilled water and ethanol before air-drying. The defatted wool $(50 \mathrm{mg})$ was immersed in $2 \mathrm{ml}$ of distilled water adjusted to $\mathrm{pH}$ 7.0, and de-aerated under reduced pressure. After adding $0.5 \mathrm{ml}$ of $1 \%$ a solution of the fatty-acylated sericin or control sericin, and incubating at $40^{\circ} \mathrm{C}$ for $15 \mathrm{~min}$ while gently shaking, the solution was filtered through glass wool, and the wool was washed with $3 \mathrm{ml}$ of distilled water. The filtrate and the washing water were collected and topped up to $10 \mathrm{ml}$ with distilled water, and the protein concentration of the diluted filtrate was meas- 
ured by the microbiuret method $^{26)}$ to evaluate the amount adsorbed to the defatted wool from the difference between the protein concentration of the initial solution and that of the diluted filtrate. The washed wool recovered was immersed in $3 \mathrm{ml}$ of distilled water adjusted to $\mathrm{pH} 7.0$ again, and incubated at $40^{\circ} \mathrm{C}$ for 15 min while gently shaking to evaluate the desorption associated with washing. The desorbed amount was measured in the same manner as that just described for adsorption.

Chemical analysis. The protein content was determined by the microbiuret method. ${ }^{26)}$ The amino acid composition was determined by an L-8800 amino acid analyzer (Hitachi, Tokyo, Japan) according to the method described in a previous paper. ${ }^{27)}$ The $\mathrm{p} I$ value was evaluated from the $\mathrm{pH}$ value of a sample solution that had been completely deionized in a mixed-bed ionexchange column (Amberlite IR120 and IRA 400, Organo Co., Tokyo, Japan) according to the method previously described. ${ }^{28)}$ The fatty acid content was determined by gas-liquid chromatography (GLC) with GC 4CM apparatus (Shimadzu, Kyoto, Japan) and a DEGS Chromosorb WAW column (GL Science, Tokyo, Japan), after fatty acid methyl esters had been prepared from samples by methanolysis according to the method previously described. ${ }^{14)}$

\section{Results and Discussion}

\section{Chemical features}

The original sericin preparation was readily soluble in distilled water, and had a main molecular weight evaluated by SEC of $18,700 \mathrm{Da}$, whereas LM sericin showed a main molecular weight of 5,000 Da. The original sericin had a very high content of serine (about $34 \mathrm{~mol} \%$ ), a high content of acidic amino acids (about $22 \mathrm{~mol} \%$ ), a low content of basic amino acids (about $7 \mathrm{~mol} \%$ ), and a low content of non-polar or hydrophobic amino acids (about $26 \mathrm{~mol} \%$ ), resulting in a low isoelectric point ( $\mathrm{p} I$ 3.83) (Table 1). The results of GLC

Table 1. Chemical Features of the Original Sericin

\begin{tabular}{|c|c|c|c|c|c|c|}
\hline \multirow{5}{*}{$\begin{array}{l}\text { Main relative molecular } \\
\quad \text { weight }(\mathrm{Da}) \\
\mathrm{p} I \text { value } \\
\text { Fatty acid content }(\%) \\
\text { Amino acid } \\
\text { composition }(\mathrm{mol} \%)\end{array}$} & \multicolumn{6}{|c|}{18,700} \\
\hline & \multicolumn{6}{|c|}{$3.83 \pm 0.03$} \\
\hline & \multicolumn{6}{|l|}{0.99} \\
\hline & & & & & & \\
\hline & Asp & 16.1 & $(17.4)^{\mathrm{a}}$ & Met & n.d. & $(<0.05)$ \\
\hline & Thr & 8.5 & $(8.0)$ & Ile & 0.5 & (0.4) \\
\hline & Ser & 34.3 & (31.0) & Leu & 1.0 & $(0.9)$ \\
\hline & Glu & 5.2 & (4.4) & Tyr & 2.1 & (3.3) \\
\hline & Pro & n.d. & $(0.4)$ & Phe & 0.9 & $(0.2)$ \\
\hline & Gly & 15.3 & (19.1) & His & 1.1 & (1.9) \\
\hline & Ala & 4.7 & (3.8) & Lys & 2.5 & (2.7) \\
\hline & Cys & n.d. & $(<0.05)$ & Arg & 3.1 & (3.9) \\
\hline & Val & 4.0 & (3.1) & & & \\
\hline
\end{tabular}

n.d., not determined.

${ }^{\mathrm{a}}$ Kato et $a l .{ }^{2)}$ showed that the original sericin, LM sericin, and control sericin samples had little respective content of fatty acid $(0.099 \%, 0.097 \%$ and $0.063 \%$ as total fatty acid) containing relatively large amounts of oleic acid and palmitic acid and a relatively small amount of stearic acid, palmitoreic acid, linoleic acid, myristic acid, and linorenic acid on the basis of each content. The yields of the fatty-acylated sericin and of the fatty-acylated LM sericin were were $8.4 \%$ and $2.9 \%$, respectively, and the fatty-acylated sericin showed the larger main molecular weight $(22,000 \mathrm{Da})$. Both the fatty-acylated sericin samples showed a considerably higher oleic acid content than the original sericin and control sericin, and the molar ratio of protein to oleic acid was 1:0.74 for the fatty-acylated sericin and 1:0.36 for the fatty-acylated LM sericin. The ${ }^{1} \mathrm{H}-\mathrm{NMR}$ spectrum of the fatty-acylated sericin showed the five peaks indicated by arrows (Fig. 1), which were not detected or were very weak for the control sericin and the original sericin, and were assigned to the chemical shifts of the alkyl, acyl, and vinyl groups of the oleic acid moiety. It is thus considered that sericin could be acylated by Novozym 435.

The secondary structural contents of the original sericin, control sericin, and fatty-acylated sericin were estimated by the second-derivative FT-IR spectra (Fig. 2). The DSC curve of the native sericin showed no endothermic peak in a temperature range of $5-180^{\circ} \mathrm{C}$ (data not shown), corresponding to the report describing a random coil structure without an $\alpha$-helix and with some $\beta$-sheet content. ${ }^{23,24)}$ The peak in this study at $1,653 \mathrm{~cm}^{-1}$ of the second-derivative FT-IR spectrum was thus assigned to an unordered structure, resulting in a large proportion of unordered structure in the original sericin and control sericin. However, the fatty-acylated sericin showed a characteristic second-derivative FT-IR spectrum rich in $\beta$-sheet. It is thus considered that the fatty acylation of sericin converted it from an unordered structure to a $\beta$-sheet-rich structure, presumably due to the structural change caused by conjugating with the hydrophobic moiety (Table 2).

\section{Improved emulsifying properties}

The emulsifying properties of the fatty-acylated sericin were evaluated by measuring the absorbance of the $\mathrm{o} / \mathrm{w}$ emulsion prepared with it. The emulsions with the native sericin and control sericin each showed a rapid decrease in the absorbance to a very low value during the initial $10 \mathrm{~min}$, being similar to the control emulsion without any additives (Fig. 3). It is thus concluded that the original sericin and control sericin had very poor emulsifying properties, probably due to poor orientation to the surface of the oil droplets because of a very high content of polar amino acids (about $73 \%$ ). The fatty-acylated sericin maintained an absorbance at a higher value than those of the sericin samples or BSA, indicative of superior emulsifying properties. The EAI value and emulsion stability were greater by 1.6 -fold 


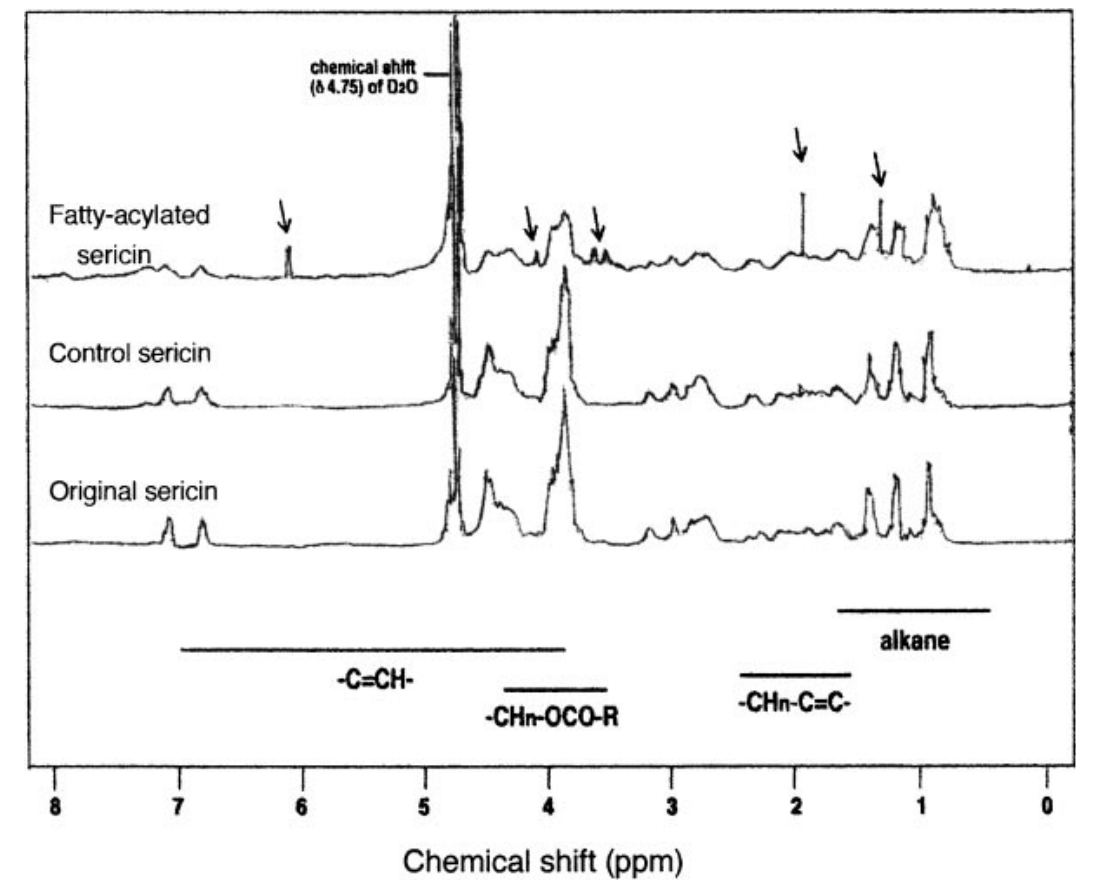

Fig. 1. Comparative ${ }^{1} \mathrm{H}-\mathrm{NMR}$ Spectra of the Fatty-Acylated Sericin, Control Sericin, and Original Sericin. The arrows indicate the chemical shifts of the alkane, aryl, acyl, and vinyl groups.

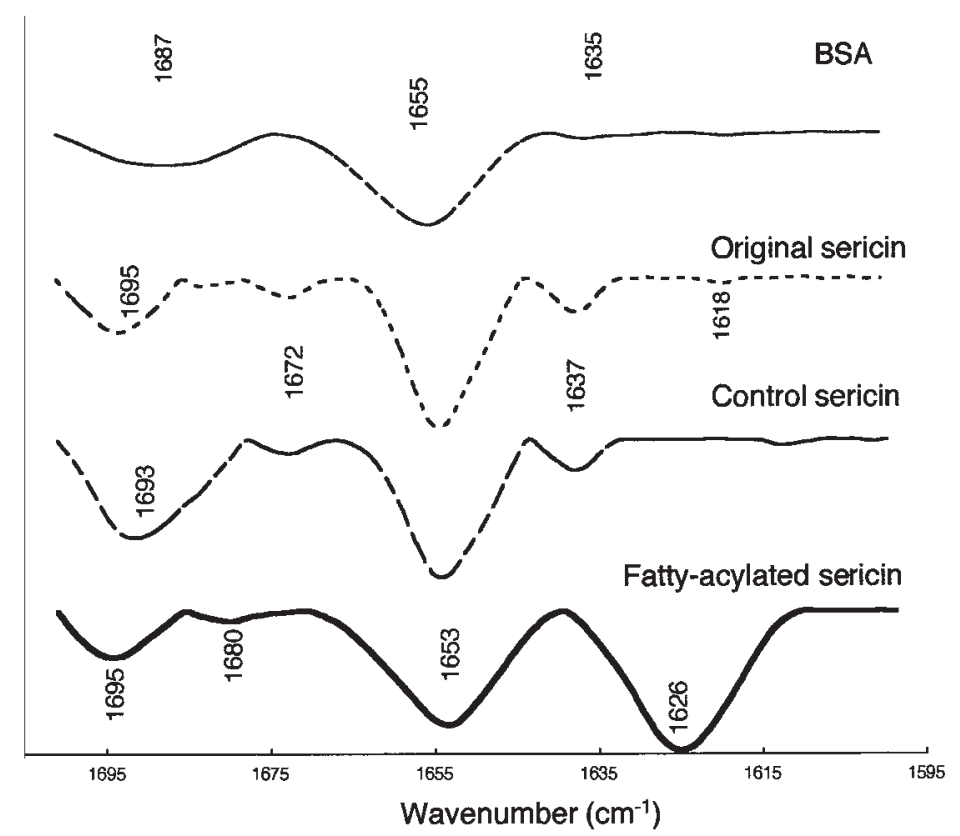

Fig. 2. Comparative Second-Derivative FT-IR Spectra for the Fatty-Acylated Sericin, Control Sericin, Original Sericin, and Bovine Serum Albumin (BSA).

See the Materials and Methods section for the FT-IR conditions.

and 4.0-fold, respectively, than those of the control sericin. The fatty-acylated LM sericin showed better emulsifying properties than the fatty-acylated sericin as demonstrated by the significantly higher EAI value than that of the fatty-acylated sericin, and by the similar emulsifying stability, although some free sericin peptide without emulsifying properties remained in its prepara- tion. This means that the fatty-acylated LM sericin preparation had superior balance between the hydrophilic peptide moiety and hydrophobic fatty acid residue than the fatty-acylated sericin, because of shorter peptide chains than those in the control sericin.

The particle size distribution of oil droplets in each emulsion was evaluated by a laser diffraction particle 
size analyzer. The median, mode, and average diameter of the oil droplets of the emulsion prepared with the fatty-acylated sericin were smaller in every diameter than those of the control sericin and BSA just after emulsification, and slightly increased $60 \mathrm{~min}$ after emulsification, indicating satisfactory emulsion stability (Table 3). However, the control sericin showed a greater mode diameter means, as especially indicated by the mode diameter of oil droplets in the upper layer of the

Table 2. Secondary Structural Contents of the Fatty-Acylated Sericin, Control Sericin, Original Sericin, and Bovine Serum Albumin (BSA) Estimated by Second-Derivative FT-IR Spectra

\begin{tabular}{lccrc}
\hline \hline \multicolumn{1}{c}{ Sample } & $\begin{array}{c}\alpha \text {-Helix } \\
(\%)\end{array}$ & $\begin{array}{c}\beta \text {-Sheet } \\
(\%)\end{array}$ & $\begin{array}{c}\text { Turns } \\
(\%)\end{array}$ & $\begin{array}{c}\text { Unordered } \\
(\%)\end{array}$ \\
\hline Fatty-acylated sericin & 0 & 58.3 & 1.5 & 40.0 \\
Control sericin & 0 & 34.6 & 11.2 & 62.0 \\
Original sericin & 0 & 40.2 & 8.3 & 51.5 \\
BSA & 70.6 & 1.9 & 26.5 & 1.0 \\
\hline
\end{tabular}

The secondary structural contents were estimated from the peak area of the second-derivative FT-IR spectrum according to the method described in the Materials and Methods section. emulsion. BSA as a proteinaceous emulsifier showed a similar mode diameter to that of the fatty-acylated sericin $60 \mathrm{~min}$ after emulsification, whereas the median and average diameters for BSA were smaller than those for the fatty-acylated sericin, indicative of a good emulsion stability. Since about two times and five times as much of the fatty-acylated sericin as the control sericin and BSA, respectively was adsorbed to the surface of the oil droplets (Table 4), through the oleic acid moiety, it is thought that the increased adsorption contributed to inhibiting the coalescence of the oil droplets. The affinity of the fatty-acylated sericin and control sericin against the $\mathrm{C}_{16}$-alkane surface as a model for the oil droplet surface was estimated by IAsys to obtain the kinetic constants. The response from the association to the $\mathrm{C}_{16}$-alkane surface was detected just after adding a sample and reached equilibrium after 3$5 \mathrm{~min}$, the increase in response depending on the sample concentration (data not shown); these data indicate rapid association to the hydrophobic surface. Since the maximum response $\left(R_{\max }\right)$ of the fatty-acylated sericin was about 1.5 times as much as that of the control
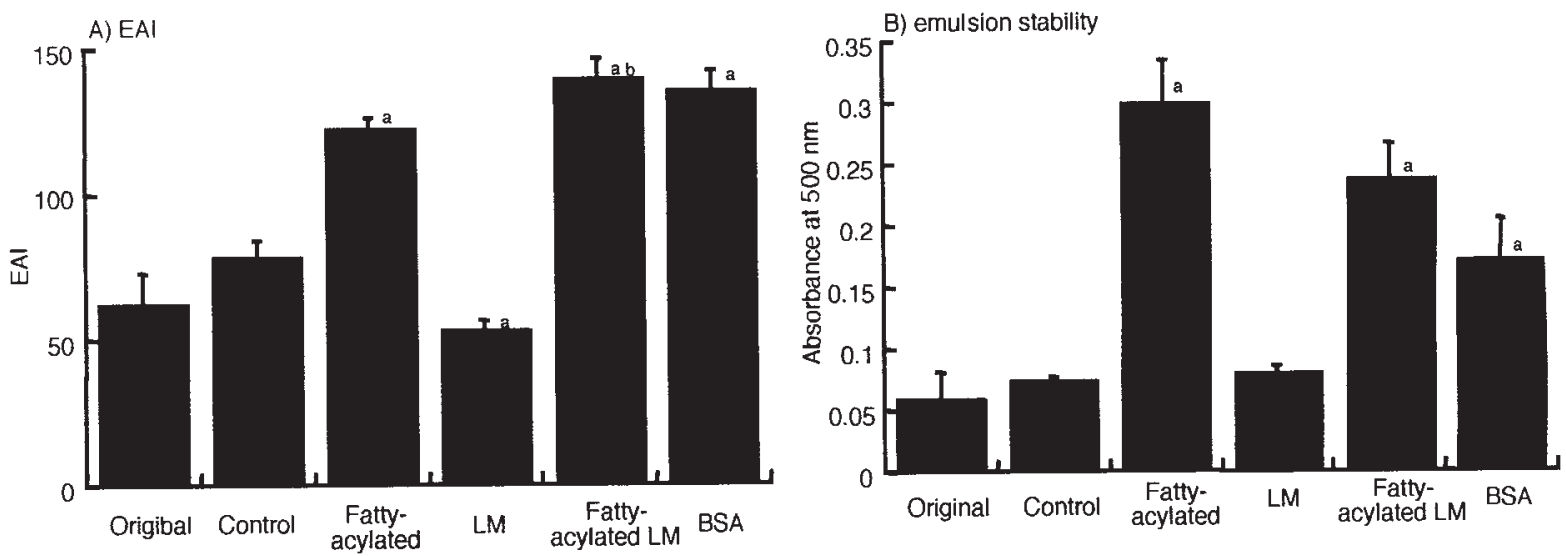

Fig. 3. Emulsifying Properties of the O/W Emulsions Prepared with the Fatty-Acylated Sericin, Control Sericin, Original Sericin, Low-MolecularWeight Sericin (LM), Fatty-Acylated LM Sericin, and Bovine Serum Albumin (BSA) Evaluated by the Emulsifying Activity Index (EAI) (A) and the Emulsion Stability (B) expressed by the Absorbance at $500 \mathrm{~nm} 60 \mathrm{~min}$ after Emulsification.

Each value is the mean \pm S.D. $(n=3)$. 'a' and 'b' show significant difference against the control and the fatty-acylated sericin, respectively, by Student's $t$ test.

Table 3. Particle Size Diameters $(\mu \mathrm{m})$ of Oil Droplets of the O/W Emulsions Prepared with the Fatty-Acylated Sericin, Control Sericin, and Bovine Serum Albumin (BAS) 0 and 60 min after Emulsification

\begin{tabular}{|c|c|c|c|c|c|c|c|c|c|}
\hline \multirow{2}{*}{ Sample } & \multicolumn{3}{|c|}{$0 \min$} & \multicolumn{3}{|c|}{$60 \mathrm{~min}$, upper layer } & \multicolumn{3}{|c|}{$60 \mathrm{~min}$, lower layer } \\
\hline & Median & Mode & Average & Median & Mode & Average & Median & Mode & Average \\
\hline $\begin{array}{l}\text { Fatty-acylated } \\
\text { sericin }\end{array}$ & 32.2 & 32.2 & 32.4 & 36.9 & 36.6 & 37.5 & 35.3 & 36.6 & 24.8 \\
\hline $\begin{array}{l}\text { Control } \\
\text { sericin }\end{array}$ & 36.9 & 39.6 & 37.4 & 53.4 & 138 & 46.8 & 32.5 & 48.8 & 21.4 \\
\hline BSA & 36.5 & 39.6 & 35.9 & 26.8 & 32.2 & 22.6 & 22.5 & 39.6 & 11.6 \\
\hline $\begin{array}{l}\text { Without } \\
\text { sample }\end{array}$ & 54.1 & 60.1 & 51.4 & 122 & 170 & 113 & 86.2 & 170 & 53.1 \\
\hline
\end{tabular}

The median, mode, and average diameters of the oil droplets of the $\mathrm{O} / \mathrm{W}$ emulsions were evaluated by a laser diffraction particle size analyzer after diluting with $0.1 \%$ SDS to give about 0.2 absorbance. 
Table 4. Protein of the Fatty-Acylated Sericin and Control Sericin Adsorbed to the Surface of Oil Droplets Immediately after Emulsification as Compared with Bovine Serum Albumin (BSA)

\begin{tabular}{llll}
\hline \hline \multirow{2}{*}{ Sample } & & Adsorbed protein \\
\cline { 2 - 4 } & $\left(\times 10^{-4} \mathrm{~g}\right)^{\mathrm{c}}$ & $\left(\times 10^{-3} \mathrm{~g} / \mathrm{m}^{2}\right)^{\mathrm{d}}$ & $\left(\times 10^{-7} \mathrm{~mol}^{\left.\mathrm{c} \mathrm{m}^{2}\right)}\right.$ \\
\hline Fatty-acylated sericin & $4.99 \pm 0.15^{\mathrm{ab}}$ & $5.36 \pm 0.16^{\mathrm{ab}}$ & $2.50 \pm 0.08^{\mathrm{ab}}$ \\
Control sericin & $1.63 \pm 0.38$ & $2.05 \pm 0.41$ & $1.20 \pm 0.22^{\mathrm{b}}$ \\
BSA & $2.33 \pm 0.29$ & $2.84 \pm 0.35$ & $0.43 \pm 0.05$ \\
\hline
\end{tabular}

Each value is the mean \pm S.D. $(n=3)$.

${ }^{\text {a }}$ Significant difference between the fatty-acylated sericin and control sericin at $P<0.01$ by Student's $t$ test.

${ }^{\text {b }}$ Significant difference between each sericin sample and BSA at $P<0.01$ by Student's $t$ test.

${ }^{\mathrm{c}}$ Total adsorbed protein.

${ }^{\mathrm{d}}$ Total adsorbed protein $\left(\times 10^{-4} \mathrm{~g}\right) /$ total surface area $\left(\mathrm{m}^{2}\right)$. The total surface area was estimated from the data for the median diameter of the oil droplets (Table 3) by the equation; (total oil volume $(0.5 \mathrm{ml})) \times($ surface area of one oil droplet with each median diameter)/(volume of one oil droplet).

Table 5. Maximum Responses and Kinetic Constants for the Association of the Fatty-Acylated Sericin, Control Sericin, and Bovine Serum Albumin (BSA) to $\mathrm{C}_{16}$-Alkane as Evaluated by IAsys

\begin{tabular}{lccc}
\hline \multicolumn{1}{c}{ Sample } & $R_{\max ^{\mathrm{a}}}$ & $K_{\text {ass }}\left(\mathrm{M}^{1-} \mathrm{s}^{-1}\right)^{\mathrm{b}}$ & $K_{\text {diss }}\left(\mathrm{s}^{-1}\right)^{\mathrm{c}}$ \\
\hline Fatty-acylated sericin & $6.28 \times 10^{2}$ & $2.57 \times 10^{4}$ & $0.92 \times 10^{-2}$ \\
Control sericin & $4.24 \times 10^{2}$ & $2.30 \times 10^{4}$ & $3.57 \times 10^{-7}$ \\
BSA & $2.20 \times 10^{2}$ & $1.08 \times 10^{4}$ & $1.03 \times 10^{-2}$ \\
\hline
\end{tabular}

${ }^{a}$ The maximum response ( $\left.\operatorname{arcsec}\right)$ was derived from the response at the saturated association in the plot of the response against the sample concentration.

${ }^{\mathrm{b}}$ The association rate constant $\left(K_{\mathrm{ass}}\right)$ was derived from the gradient of the of the plot of the pseudo first-order rate constant $\left(K_{\mathrm{on}}\right)$ against the sample concentration.

${ }^{\mathrm{c}}$ The dissociation rate constant $\left(K_{\text {diss }}\right)$ was derived from the intercept of the of the plot of $K_{\text {on }}$ against the sample concentration.

${ }^{\mathrm{d}}$ The dissociation constant $\left(K_{\mathrm{D}}\right)$ was obtained from $K_{\text {diss }} / K_{\text {ass }}\left({ }^{\mathrm{c}} /{ }^{\mathrm{b}}\right)$
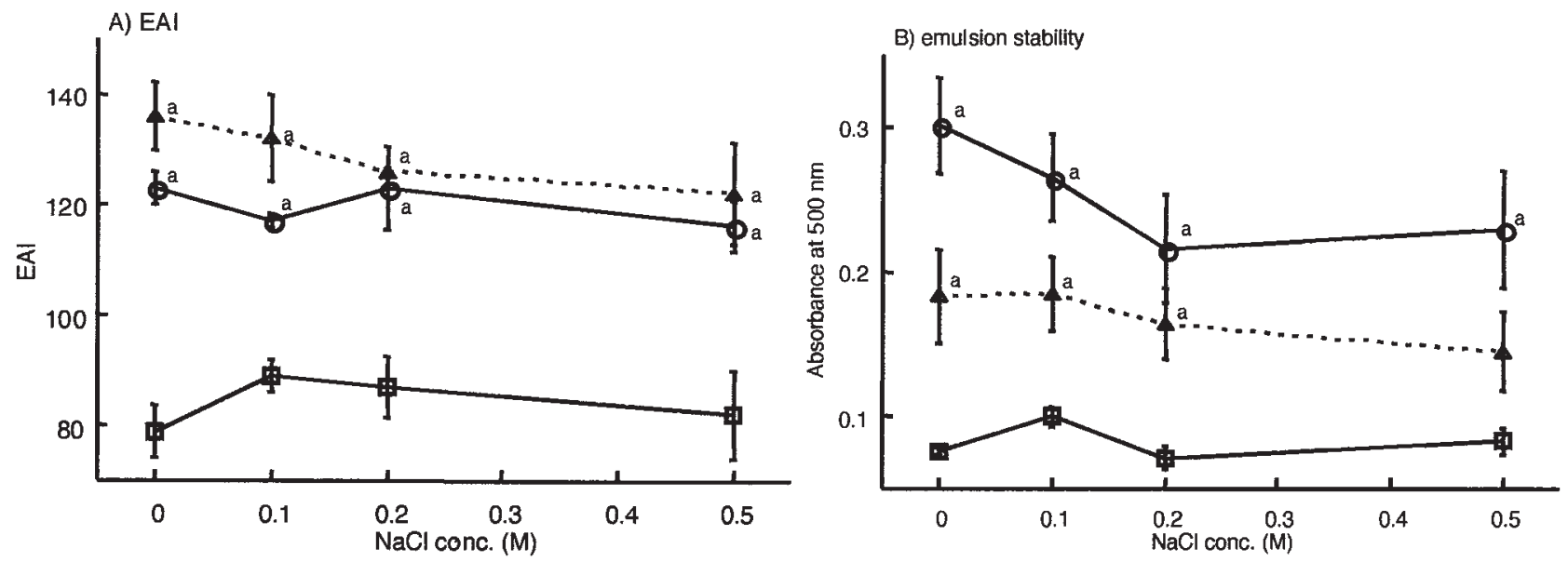

Fig. 4. Comparative Effects of $\mathrm{NaCl}$ Concentration on the Emulsifying Activity Index (EAI) (A) and Emulsion Stability (B) of the Fatty-Acylated Sericin $(\bigcirc)$, Control Sericin $(\square)$, and Bovine Serum Albumin (BSA, $\mathbf{\Delta}$ ).

Each value is the mean \pm S.D. $(n=3)$. 'a' shows significant difference against the control sericin by Student's $t$ test.

sericin (Table 5), the amount of the fatty-acylated sericin associated to the hydrophobic surface was double, corresponding well to the increase in the adsorbed amount from the results (Table 4) of a chemical analysis. Since $K_{\mathrm{D}}$ (the dissociation constant) of the fatty-acylated sericin was about $1 / 2$ of that of the control sericin, it is considered that the acylation of sericin could improve by twice the affinity to the hydrophobic surface.

The effects of several environmental factors on the emulsifying properties were next studied. The effect of sodium chloride was investigated for emulsions con- taining $0.1,0.2$, and $0.5 \mathrm{M} \mathrm{NaCl}$ at $\mathrm{pH} 7.0$, because salts easily reduce the emulsifying ability of fatty-acylated sucrose $^{29)}$ and protein ${ }^{27,30)}$ due to the salting out-effect. The fatty-acylated sericin showed significantly higher EAI than the control sericin (Fig. 4). The emulsion stability of the fatty-acylated sericin also showed higher levels than those of the control sericin and BSA. These results indicate that the fatty-acylated sericin maintained the emulsifying properties even in the presence of $0.5 \mathrm{M}$ $\mathrm{NaCl}$. Since sericin has a very high content of polar amino acids (about 73\%), the observed salt tolerance is considered to have resulted from the high solubility and 

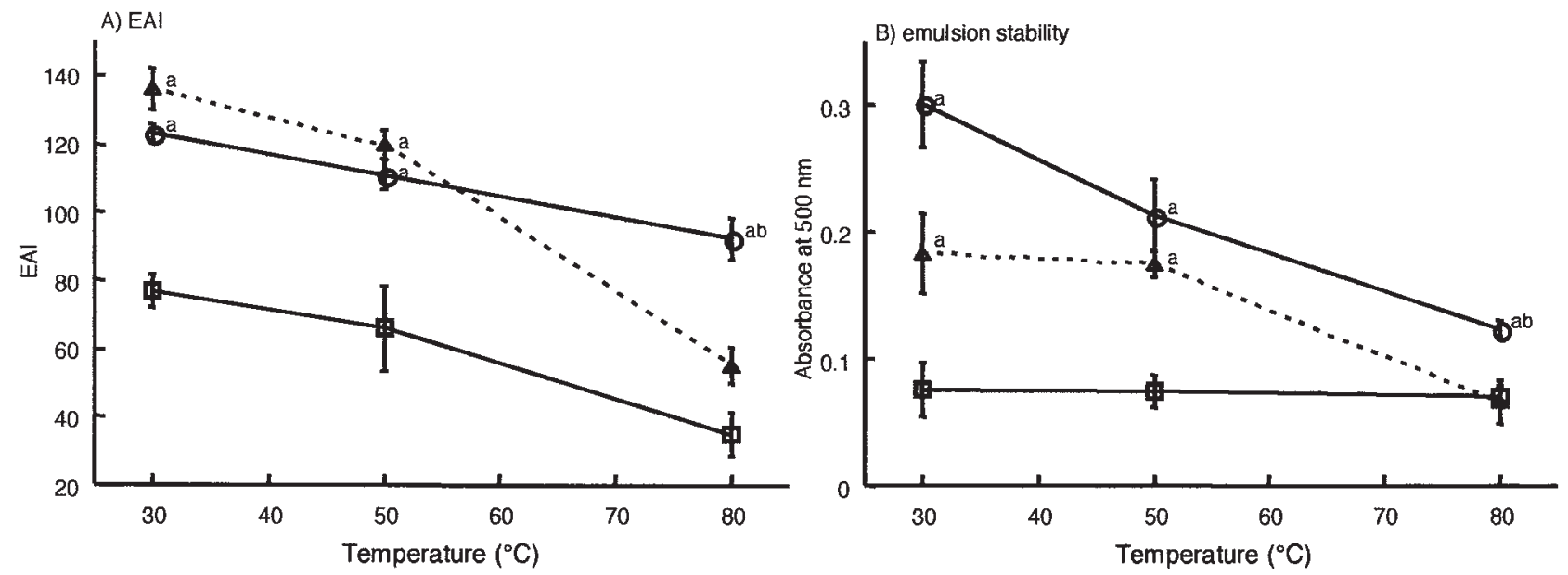

Fig. 5. Comparative Effects of Temperature on the Emulsifying Activity Index (EAI) (A) and Emulsion Stability (B) of the Fatty-Acylated Sericin $(\bigcirc)$, Control Sericin $(\square)$, and Bovine Serum Albumin (BSA, $\mathbf{\Delta}$ )

Each value is the mean \pm S.D. $(n=3)$. ' $a$ ' and ' $b$ ' show significant difference against the control sericin and fatty-acylated sericin, respectively, by Student's $t$ test.
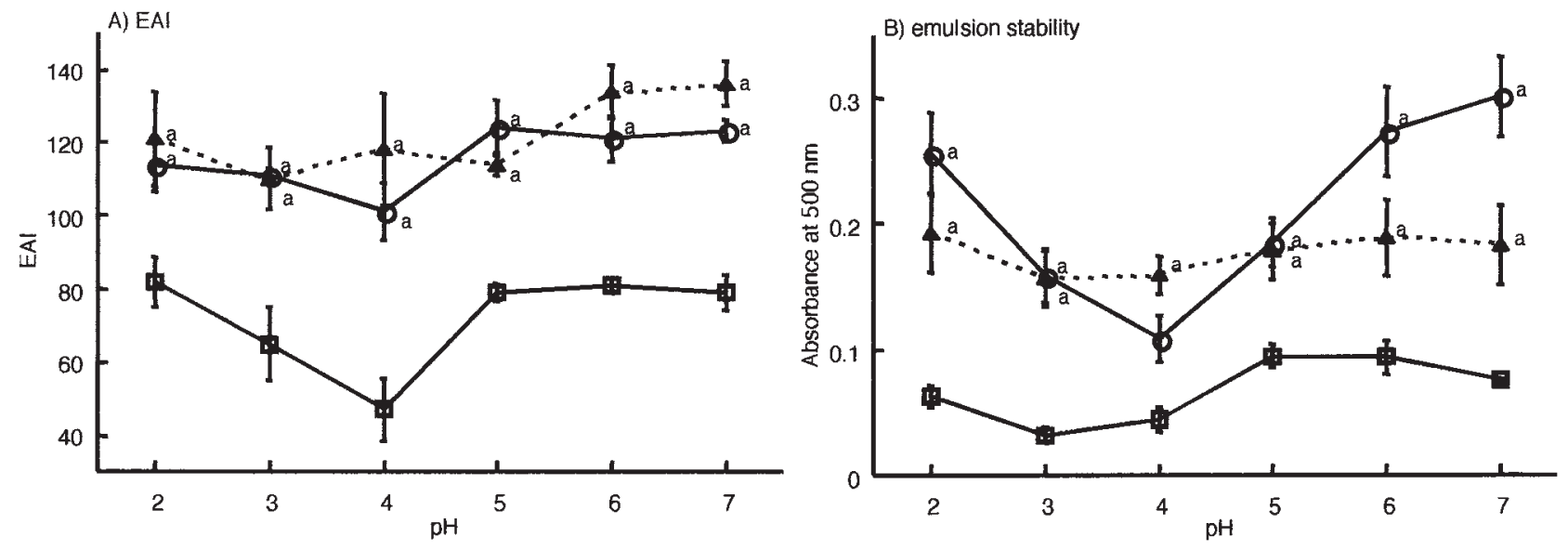

Fig. 6. Comparative Effects of $\mathrm{pH}$ on the Emulsifying Activity Index (EAI) (A) and Emulsion Stability (B) of the Fatty-Acylated Sericin ( $\bigcirc$ ), Control Sericin $(\square)$, and Bovine Serum Albumin (BSA, $\mathbf{\Delta}$ ).

Each value is the mean \pm S.D. $(n=3)$. 'a' shows significant difference against the control sericin by Student's $t$ test.

ion-exchange capacity of the sericin moiety. The effect of temperature on the emulsifying properties was evaluated by measuring the absorbance of emulsions prepared with the sample solutions heated at 30,50 , or $80^{\circ} \mathrm{C}$ for $1 \mathrm{~h}$ and then held at the same temperature. The fatty-acylated sericin showed only a small decrease in EAI over the temperature range of $30-80^{\circ} \mathrm{C}$, whereas BSA showed considerably reduced EAI at $80^{\circ} \mathrm{C}$ (Fig. 5), probably due to thermal denaturation. Although the emulsion stability of the fatty-acylated sericin decreased with increasing temperature, it showed higher emulsion stability than the other samples. The effect of $\mathrm{pH}$ on the emulsifying properties was evaluated for emulsions prepared at $\mathrm{pH} 2.0,3.0,4.0,5.0,6.0$, and 7.0. For the sample solution at $\mathrm{pH} 4.0$, the centrifugal supernatant (about $14,000 \times g, 20 \mathrm{~min}$ ) was used to eliminate some isoelectric precipitates, giving a $0.035 \%$ solution. The emulsions prepared with the fatty-acylated sericin exhibited high EAI at every $\mathrm{pH}$ value, except for a small decrease at $\mathrm{pH} 4.0$ due to the decrease in sample concentration, similar to those of BSA (Fig. 6), indicating good emulsifying activity over a wide $\mathrm{pH}$ range. However, the emulsion stability of the fatty-acylated sericin considerably decreased to the values for BSA in the $\mathrm{pH}$ range of 3.0-5.0, probably due to a decrease in the solubility and electrostatic repulsion toward $\mathrm{p} I$ of sericin.

\section{Moistness property}

The vaporization behavior of water in the fattyacylated sericin solution was investigated by TG/DTA to evaluate its moistness property. TG curves of the fatty-acylated sericin and control sericin solutions were in a higher temperature region than that of distilled water (data not shown), indicating moistness due to the retarded vaporization. DTG curves were then derived to 
Table 6. Vaporization Characteristics Evaluated by TG/DTA of the Fatty-Acylated Sericin, and Control Sericin as Compared with Distilled Water

\begin{tabular}{lccc}
\hline \multicolumn{1}{c}{ Sample } & $T_{V_{\max }{ }^{\mathrm{a}}}$ & $V_{\max }{ }^{\mathrm{b}}$ & $T_{\text {end } V^{\mathrm{c}}}$ \\
\hline Fatty-acylated sericin & $95.2 \pm 5.2^{\mathrm{e}}$ & $11.9 \pm 0.12$ & $123.8 \pm 0.3^{\mathrm{e}}$ \\
Control sericin & $95.1 \pm 0.3^{\mathrm{e}}$ & $11.8 \pm 0.03^{\mathrm{e}}$ & $124.0 \pm 0.3^{\mathrm{e}}$ \\
Distilled water & $93.4 \pm 0.2$ & $12.1 \pm 0.04$ & $0.43 \pm 0.01^{\mathrm{ef}}$ \\
\hline
\end{tabular}

Each value is the mean \pm S.D. $(n=3)$.

${ }^{a}$ The temperature at the maximum rate of vaporization $\left(T_{V_{n}}\right)$ was determined as the temperature at the peak top of the DTG curve.

${ }^{\mathrm{b}}$ The maximum velocity of vaporization $\left(V_{\max }\right)$ was determined as the vaporization rate at the peak top of the DTG curve.

${ }^{\mathrm{c}}$ The temperature at the end vaporization $\left(T_{\text {end } V}\right)$ was determined as the extrapolated temperature around $120^{\circ} \mathrm{C}$.

${ }^{\mathrm{d}}$ The rate of end vaporization $\left(V_{\text {end }}\right)$ was determined as the vaporization rate at the extrapolated temperature around $120^{\circ} \mathrm{C}$.

e Significant difference between each sericin sample and distilled water at $P<0.05$ by Student's $t$ test.

${ }^{\mathrm{f}}$ Significant difference between the fatty-acylated sericin and control sericin at $P<0.05$ by Student's $t$ test.

Table 7. Protein of the Fatty-Acylated Sericin and Control Sericin Adsorbed to the Defatted Wool as Compared with Bovine Serum Albumin (BSA)

\begin{tabular}{|c|c|c|c|}
\hline \multirow[b]{2}{*}{ Sample } & \multicolumn{2}{|c|}{ Adsorption } & \multirow{2}{*}{$\begin{array}{l}\text { Residual protein } \\
\text { after washing } \\
\text { (g/100 g of wool) }\end{array}$} \\
\hline & $\begin{array}{l}\text { Adsorbed protein }{ }^{\mathrm{a}} \\
\text { (g/100 g of wool) }\end{array}$ & $\begin{array}{l}\text { Adsorption }{ }^{\mathrm{b}} \\
(\%)\end{array}$ & \\
\hline Fatty-acylated sericin & $2.42 \pm 0.9^{\mathrm{d}}$ & $11.8 \pm 4.4^{\mathrm{de}}$ & $2.43 \pm 0.97^{\mathrm{d}}$ \\
\hline Control sericin & $0.55 \pm 0.4$ & $2.6 \pm 2.3$ & $0.52 \pm 0.46$ \\
\hline BSA & $0.71 \pm 0.5$ & $3.2 \pm 2.5$ & $0.69 \pm 0.54$ \\
\hline
\end{tabular}

Each value is the mean \pm S.D. $(\mathrm{n}=3)$.

${ }^{a}$ Derived from the reduced protein concentration after immersing the defatted wool in $1 \%$ of each sample solution at $40{ }^{\circ} \mathrm{C}$ for 15 min.

${ }^{\mathrm{b}}$ Percentage of the amount of adsorbed protein to the initial protein amount of each solution.

${ }^{\mathrm{c}}$ Derived from the released protein concentration after washing with distilled water at $40{ }^{\circ} \mathrm{C}$ for $15 \mathrm{~min}$.

${ }^{\mathrm{d}}$ Significant difference between each sericin sample and BSA at $P<0.05$ by Student's $t$ test.

e Significant difference between the fatty-acylated sericin and control sericin at $P<0.05$ by Student's $t$ test.

evaluate the state of vaporization of water restrained by the fatty-acylated sericin and control sericin. The $T_{V_{\max }}$ and $T_{\text {end } V}$ values for the fatty-acylated sericin and control sericin were significantly higher (about $2{ }^{\circ} \mathrm{C}$ ) than those of distilled water, although there was no significant difference between the fatty-acylated sericin and control sericin (Table 6). This similarity indicates that the fatty-acylated sericin had similar water-holding capacity to that of the control sericin. The fatty-acylated sericin and control sericin solutions showed smaller $V_{\max }$ and larger $V_{\text {end }}$ values than distilled water. It is thus considered that the fatty-acylated sericin could retain its water content in a similar manner to that of the control sericin. These results indicate that the fatty-acylated sericin could maintain a moistness property similar to that of the control sericin.

\section{Adsorption to the surface of defatted wool}

The high affinity to a hydrophobic surface and moistness property of the fatty-acylated sericin suggest that the level of moistness would be prolonged, resulting in improved physical properties such as flexibility, if it can be stably bound on the surface of the material, article, skin, or hair. Defatted wool, a highly insoluble fibrillar scleroprotein, was used in this study as a model to elucidate the adsorption of the fatty-acylated sericin to its surface. The amount of the fatty-acylated sericin adsorbed to the defatted wool was respectively about four times and three times higher than those of the control sericin and BAS (Table 7). In addition, little desorption was apparent after washing with warm distilled water. These results indicate that the fattyacylated sericin had superior adsorption ability to the wool surface, probably due to the presence of a hydrophobic moiety acylated by lipase. It is thus reasonable to expect that fatty acylation could endow foods, edible films, skin, and hair with such valuable interfacial properties as moistness and flexibility. The results of this study will possibly contribute to the development of a novel acylated sericin as a valuable emulsifier and moistness modifier for foods and cosmetics.

\section{Acknowledgments}

We are grateful to Jun-ichi Kitagawa of Sinkosilk Ltd. and Kyoko Abe of Novozyme Japan Co. for generously supplying the sericin solution and Novozym 435, respectively. We are also grateful to Professor Kazuhiro Chiba of Tokyo University of Agriculture and Technology, Mitsuru Maruyama of Shimadzu Co., Hiroki Ito of Hitachi High-Technologies Co., and Yoshitoshi Nishiyama of SSI Nanotechnologies Co. for respectively measuring ${ }^{1} \mathrm{H}-\mathrm{NMR}$, the particle size analysis, IAsys, and TG/DTA.

\section{References}

1) Fournier, A., Quantitative data on the Bombyx mori L. silk worm. Biochimie, 61, 283-320 (1979).

2) Kato, N., Sato, S., Yamanaka, A., Yamada, H., Fuwa, N., and Nomura, M., Silk protein, sericin, inhibits lipid 
peroxidation and tyrosinase activity. Biosci. Biotechnol. Biochem., 62, 145-147 (1998).

3) Voegeli, R., Sericin silk protein: unique structure and properties. Cosmetics Toiletries, 108, 101-108 (1993).

4) Tsujimoto, K., Takagi, M., Takahashi, M., Yamada, H., and Nakamori, S., Cryoprotective effect of the sericinrich repetitive sequence in silk protein sericin. $J$. Biochem., 129, 979-986 (2001).

5) Sasaki, M., Yamada, H., and Kato, N., A resistant protein, sericin, improves atropin-induced constipation in rats. Food Sci. Technol. Res., 6, 280-283 (2000).

6) Sasaki, M., Yamada, H., and Kato, N., Consumption of silk protein, sericin, elevates intestinal absorption of zinc, iron, magnesium and calcium in rats. Nutr. Res., 20, 1505-1511 (2000).

7) Zhaorigetu, S., Sakaki, M., Watanabe, H., and Kato, N., Supplemental silk protein, sericin, suppresses tumorigenesis in 1,2-dimethylhydrazine-treated mice by reducing oxidative stress and cell proliferation. Biosci. Biotechnol. Biochem., 65, 2181-2186 (2001).

8) Zhang, Y.-Q., Applications of natural silk protein sericin in biomaterials. Biotechnol. Adv., 20, 91-100 (2002).

9) Tamada, Y., Sano, M., Niwa, K., Imai, T., and Yoshino, G., Sulfation of silk sericin and anticoagulant activity of sulfated sericin. J. Biomat. Sci. Polym. Ed., 15, 971-980 (2004).

10) Haque, Z., Matoba, T., and Kito, M., Incorporation of fatty acid into food protein: palmitoyl soybean glycinin. J. Agric. Food Chem., 30, 481-486 (1982).

11) Haque, Z., and Kito, M., Lipophilization of $\alpha$-S1-casein. 1. Covalent attachment of palmitoyl residue. J. Agric. Food Chem., 31, 1225-1230 (1983).

12) Ibrahim, H. R., Kato, A., and Kobayashi, K., Antimicrobial effects of lysozyme against gram-negative bacteria due to covalent binding of palmitic acid. $J$. Agric. Food Chem., 30, 2077-2082 (1991).

13) Ibrahim, H. R., Kobayashi, K., and Kato, A., Length of hydrocarbon chain and antimicrobial action to gramnegative bacteria of fatty acylated lysozyme. J. Agric. Food Chem., 41, 1164-1168 (1993).

14) Takahashi, K., Lou, X.-F., Ishii, Y., and Hattori, M., Lysozyme-glucose stearic acid monoester conjugate formed through the Maillard reaction as an antibacterial emulsifier. J. Agric. Food Chem., 48, 2044-2049 (2000).

15) Kobata, K., Kawaguchi, M., and Watanabe, T., Enzymatic synthesis of a capsinoid by acylation of vanillyl alcohol with fatty acid derivatives catalyzed by lipase. Biosci. Biotechnol. Biochem., 66, 319-327 (2002).

16) Bradoo, S., Saxena, R. K., and Gupta, R., High yields of ascorbyl palmitate by thermostable lipase-mediated esterification. J. Am. Oil Chem. Soc., 76, 1291-1295 (1999).

17) Pereira, C. C., de Silva, M. A., and Langone, M. A., Enzymatic synthesis of monolaurin. Appl. Biochem. Biotechnol., Spring, 113-116, 433-445 (2004).

18) Larios, A., Garcia, H. S., Oliart, R. M., and ValerioAlfaro, G., Synthesis of flavor and fragrance esters using Candida antratica lipase. Appl. Microbiol. Biotechnol., 65, 373-376 (2004).

19) Cao, L., Bornscheuer, U. T., and Schmid, R. D., Lipasecatalyzed solid phase synthesis of sugar esters. Biocatal. Biotransform., 14, 269-283 (1997).

20) Takahashi, K., Yamamoto, H., Yokote, Y., and Hattori, M., Thermal behavior of fowl feather keratin. Biosci. Biotechnol. Biochem., 68, 1875-1881 (2004).

21) Dong, A., Hung, P., and Caughey, W. S., Protein secondary structure in water from secondary-derivative amide I infrared spectra. Biochem., 29, 3303-3308 (1990).

22) Beer, M., Sutherland, G. B. B. M., Tanner, K. N., and Wood, D. L., Infrared spectra an structure of protein. Proc. Roy. Soc., 249, 147-172 (1959).

23) Komatsu, K., Chemical and structural studies on silk sericin. Proc. 7th Int. Wool Text. Res. Conf., 1, 372-382 (1985).

24) Lee, K., Kweon, H., Woo, S.-O., Lee, Y.-W., Kim, K.-H., and Park, Y.-H., Effect of methyl alcohol on the morphology and conformational characteristics of silk sericin. Int. J. Biol. Macromol., 33, 75-80 (2003).

25) Pearce, K. M., and Kinsella, J. E., Emulsifying properties of proteins: evaluation of a turbidimetric technique. J. Agric. Food Chem., 26, 716-723 (1978).

26) Itzaki, R. F., and Gill, D. M., A micro-biuret method for estimating proteins. Anal. Biochem., 9, 401-410 (1964).

27) Hattori, M., and Takahashi, K., Pepsin-solubilized elastin as a water/oil emulsifier. Food Hydrocolloids, 7, 327-335 (1993).

28) Nakazaki, S., Takaku, K., Yuguchi, M., Edamatsu, H., and Takahashi, K., Regulation of molecular structure of acid-dispersed collagen with alkaline pretreatment. Animal Sci. Technol., 65, 1018-1025 (1994).

29) Yamagishi, Y., Hattori, M., Yoshida, T., and Takahashi, $\mathrm{K}$., Improvement of the functional properties of sucrose stearate by phosphorylation. J. Agric. Food Chem., 52, 8039-8045 (2004).

30) Nagasawa, K., Takahashi, K., and Hattori, M., Improved emulsifying properties of $\beta$-lactoglobulin by conjugating with carboxymethyl dextran. Food Hydrocolloids, 10, 63-67 (1996). 